\title{
THE DISTINCTION LAW OF PROCEDURE OF CORRUPTION CASE AND THE GENERAL COURT IN INDONESIAN CRIMINAL JUSTICE SYSTEM
}

\section{PERBEDAAN HUKUM ACARA PENGADILAN TINDAK PIDANA KORUPSI DENGAN PENGADILAN UMUM DALAM SISTEM PERADILAN PIDANA INDONESIA*}

\author{
Sukmareni $^{1}$, Roni Efendi ${ }^{2}$, Riki Zulfiko ${ }^{3}$ \\ ${ }^{1}$ Fakultas Hukum Universitas Muhamadiyah Sumatera Barat \\ Komplek Parupuk Raya Blok E. No 21 Tabing Padang \\ *e-mail: sukmarenirajab@yahoo.com \\ ${ }^{2}$ Fakultas Syariah IAIN Batusangkar \\ Perum Bukit Bintang Rizano, Bukik Gombak, Tanah Datar \\ e-mail: roniefendi@iainbatusangkar.ac.id \\ ${ }^{3}$ Fakultas Hukum Universitas Muhammadiyah Sumatera Barat \\ J1 By Pass Aur Kuning Bukittingi \\ e-mail : rikiabumufid@gmail.com
}

\begin{abstract}
The Corruption Crime Court which based on Article 5 of the corruption Court Law has the authority to examine, adjudicate and decide on the corruption crime cases, money laundering crimes that was initiated by corruption crime and criminal acts that are expressly stipulated in other laws that considered as corruption act. The existence of sovereignty possessed by the State gives rise to jurisdiction (the authority to judge) in regulating the needs of the state both internally and externally. As a sovereign country, Indonesia has jurisdiction in resolving internal and external problems. There are three questions of the research; 1) What is the procedural law of the General Court in the Indonesian criminal justice system? 2) What is the procedural law of the Corruption Crime Court in the Indonesian criminal justice system?, 3) What is the difference between the procedural law of the Corruption Crime Court compared to the law of the General Court in the Indonesian criminal justice system ?.This research is hoped that the procedural laws used in the General Courts and the Corruption Crime Courts will be known, as well as the differences in the procedural laws used in the two Courts. This research is descriptive, using a normative juridical approach, especially the legal approach, used are secondary data as the main legal material in the form of laws relating to the procedural law of general courts and Corruption Crime courts. and qualitative analisis. Based on the research, it was found that differences in the procedural law of Corruption Crime courts compared to general court procedural law in the Indonesian criminal justice system were seen in the independence of the Corruption Crime court institutions and the material that became the authority and the judicial process with the composition and members of the Panel of Judges consisting of career judges and ad hoc judges. division of duties for the presiding judge and its members, the period of time for the examination of the Corruption Crime and the evidence used, as well as their secret registrations which are also special in nature.
\end{abstract}

Key words: Procedural Law; Corruption.

\section{Abstrak}

Pengadilan TPK berdasarkan Pasal 5 UU Pengadilan TPK, berwenang memeriksa, mengadili dan memutus perkara TPK, tindak pidana pencucian uang (TPPU) yang tindak pidana asalnya TPK, dan/atau tindak pidana yang secara tegas dalam undang-undang lain ditentukan

\footnotetext{
* Naskah diterima: 23 Februari 2021, direvisi: 11 Maret 2021, disetujui untuk terbit: 25 Maret 2021

Doi: $10.3376 /$ jch.v6i2.337
} 
sebagai TPK. Adanya kedaulatan yang dimiliki oleh Negara memunculkan yurisdiksi (kewenangan mengadili) dalam mengatur kebutuhan negara tersebut baik internal maupun eksternal. Sebagai Negara yang berdaulat Indonesia mempunyai yurisdiksi dalam menyelesaikan masalah internal dan eksternalnya. mengangkat permasalahan 1) Bagaimana hukum acara dari Pengadilan Umum dalam sistem peradilan pidana Indonesia?, 2) Bagaimana hukum acara dari Pengadilan TPK dalam sistem peradilan pidana Indonesia ?, 3) Apa perbedaan hokum acara Pengadilan TPK dibandingkan dengan hukum Pengadilan Umum dalam sistem peradilan pidana Indonesia?. Melalui penelitian ini diharapkan akan dapat diketahui hokum acara yang digunakan pada Pengadilan Umum dan Pengadilan TPK, serta perbedaan hokum acara yang digunakan dalam kedua Pengadilan tersebut. Penelitian ini bersifat deskriptif, menggunakan pendekatan yuridis normatif khususnya pendekatan undang-undang. Data yang digunakan adalah data sekunder sebagai bahan hukum utama berupa perundang-uangan yang berkaitan dengan hokum acara pengadilan umum dan pengadilan TPK. Semua bahan hokum yang terkumpul dilakukan alias secara kualitatif. Berdasarkan penelitian ditemukan perbedaan hukum acara pengadilan tpk dibandingkan dengan hukum acara pengadilan umum dalam sistem peradilan pidana indonesia terlihat pada independensi/kemandirian lembaga pengadilan TPK dan materi yang menjadi kewenangan dan proses peradilannya dengan susunan dan anggota Majelis Hakimnya yang terdiri atas hakim karir dan hakim adhoc, pembagian tugas hakim ketua dan anggotanya, jangka waktu pemeriksaan TPK dan pembuktian yang digunakan, serta kepaniteraannya yang juga bersifat khusus.

Kata Kunci: Hukum Acara; Tindak Pidana Korupsi.

\section{PENDAHULUAN}

Pengadilan merupakan benteng terakhir dalam melawan ketidak adilan, oleh sebab itu maka pengambilan keputusan oleh hakim yang independen di Pengadilan harus dilakukan melalui suatu proses baik proses administrasi perkara maupun proses persidangan. Dimana kata pengadilan dan Peradilan keduanya memiliki kata dasar yang sama yaitu adil, yang berarti (Ahmad Mujahidin, 2007) :

\section{a. Proses mengadili}

b. Upaya untuk mencari keadilan

c. Penyelesaian sengketa hokum di hadapan badan peradilan

d. Berdasarkan hukum yang berlaku

Tindak pidana korupsi (TPK) menurut penjelasan Umum UndangUndang Nomor 46 Tahun 2009 tentang Pengadilan Tindak Pidana Korupsi Pengadilan TPK 2009) adalah tindak pidana sebagaimana dimaksud dalam
Undang-Undang Nomor 31 Tahun 1999 tentang Pemberantasan Tindak Pidana Korupsi sebagaimana telah diubah dengan Undang Undang Nomor 20 Tahun 2001 tentang Perubahan Atas Undang Undang Nomor 31 Tahun 1999 tentang Pemberantasan Tindak Pidana Korupsi (UU TPK).

Indonesia sebagai salah satu Negara yang telah meratifikasi Konvensi PBB Anti Korupsi, menjadikan kejahatan korupsi menjadi berkualifikasi internasional, sehingga dituntut untuk dapat melakukan pemberantasan korupsi secara efektif dengan mempergunakan sistem hukum nasionalnya melalui instrumen-instrumen hukum yang terkait dengan korupsi. Hal ini disebabkan korupsi sudah meluas dan sistematis yang melanggar hak-hak ekonomi masyarakat, sosial, politik dan budaya bangsa. Kemudian dengan diberlakukannya Undang-Undang No. 30 Tahun 2002 
Sukmareni, Roni Efendi dan Riki Zulfiko: Perbedaan Hukum Acara Pengadilan Tindak...

tentang Komisi Pemberantasan Tindak Pidana Korupsi (KPK) yang mengklasifikasikan kejahatan korupsi sebagai kejahatan luar biasa (extra ordinary crimes), karena korupsi di Indonesia sudah meluas dan sistematis yang melanggar hak-hak ekonomi masyarakat. Untuk itu memerlukan caracara pemberantasan korupsi yang luar biasa. sehingga memerlukan cara-cara pemberantasan yang luar biasa pula (Extra ordinary instrument). (Artidjo Alkostar, 2013)

Sehubungan dengan hal tersebut, melihat penegakan hukum yang dilakukan untuk mempersempit ruang gerak para koruptor secara konvensional selama ini terbukti mengalami berbagai rintangan sehingga membuat masyarakat tidak percaya terhadap masa depan penegakan hukum, Menurunnya kepercayaan ini disebabkan adanya aparat penegak hukum yang nakal sehingga timbul adanya mafia peradilan (judicial corruption) di lingkungan peradilan. Berdasarkan hal di atas diperlukan metode penegakan hukum dalam suatu badan khusus yang mempunyai kewenangan luas, independen serta bebas dari kekuasaan manapun dalam upaya pemberantasan tindak pidana korupsi yang efektif dan professional (Titin Apriani, 2019)

Sementara kerusakan yang ditimbulkan oleh TPK dalam berbagai sendi kehidupan masyarakat, bangsa dan Negara, dalam bagian menimbang UU Pengadilan TPK ditegaskan menuntut upaya pencegahan dan pemberantasan secara terus menerus dan berkesinambungan melalui peningkatan kapasitas sumber daya kelembagaan, sumber daya manusia dan lainnya, salah satunya mengenai Pengadilan TPK sebagai lembaga yang berwenang memeriksa, memproses dan memutus TPK. Reformasi lingkungan peradilan di bidang kekuasaan kehakiman ini dilator belakangi dari ketidakpuasan masyarakat terhadap kinerja lembaga peradilan dan para aparatnya yang dinilai sering mengabaikan tercapainya putusan pengadilan yang jujur, tidak memihak dan berkualitas yang mengarah pada kegiatan mafia peradilan. (H Nurdin, 2019)

Pengadilan TPK pada awalnya dibentuk berdasarkan Pasal 53 UU KPK, kewenangannya hanya sebatas memeriksa dan memutus TPK yang penuntutannya diajukan oleh KPK, sedangkan TPK yang diajukan oleh Kejaksaan tetap diadili oleh Pengadilan negeri biasa. Dualisme penanganan TPK ini berdasarkan putusan Mahkamah Konstitusi (MK ) dengan Putusan Nomor 019/PUUIV/2006 tanggal 19 Desember 2006 bertentangan dengan Pasal 24 ayat (5) Undang-Undang Dasar Negara Republik Indonesia Tahun 1945 (UUD 1945), sekaligus memerintahkan keberadaan Pengadilan TPK untuk diatur kembali melalui undang-undang paling lambat 19 Desember 2009. Hal ini diwujudkan dengan ditetapkannya UU Pengadilan TPK 2009.

Pengadilan TPK berdasarkan Pasal 5 UU Pengadilan TPK, berwenang 
memeriksa, mengadili dan memutus perkara TPK, tindak pidana pencucian uang (TPPU) yang tindak pidana asalnya TPK, dan/atau tindak pidana yang secara tegas dalam undang-undang lain ditentukan sebagai TPK. Adanya kedaulatan yang dimiliki oleh Negara memunculkan yurisdiksi (kewenangan mengadili) dalam mengatur kebutuhan negara tersebut baik internal maupun eksternal. Sebagai Negara yang berdaulat Indonesia mempunyai yurisdiksi dalam menyelesaikan masalah internal dan eksternalnya (Kurniasanti et all, 2020).

Hukum pidana memiliki fungsi sebagai instrument untuk mengatur hidup kemasyarakatan dan menyelenggarakan tata tertib dalam masyarakat, juga memberikan perlindungan terhadap kepentingan hukum para pelaku. Oleh karena itu jika pelaksanaan aturan hukum pidana tidak dilakukan oleh aparat hukum dengan baik, maka fungsi hokum itu tidak akan tercapai ( Rikhi Benindo Maghaz', 2019). Aparat penegak hokum merupakan salah satu faktor penegakan hokum yang bertugas menerapkan aturan hukum yang berlaku, melalui pemberian pelayanan yang adil, perlindungan pada masyarakat dan para saksi, baik untuk kepentingan penyidikan, penuntutan maupun pada saat pemeriksaan di siding pengadilan, serta penerapan sanksi pidana sebagai suatu operasionalisasi hukum (ius operatum) berhubungan dengan kewenangan penegakan hokum

Pasal 24 ayat (1) amandemen UUD 1945 dengan tegas menyebutkan bahwa kekuasaan kehakiman merupakan kekuasaan yang merdeka untuk menyelenggarakan peradilan guna menegakkan hukum dan keadilan, yang dilakukan oleh sebuah Mahkamah Agung dan badan peradilan yang berada di bawahnya dalam lingkungan peradilan umum, peradilan agama, peradilan militer, peradilan tata usaha Negara, dan oleh sebuah Mahkamah Konstitusi

Penetapan Pengadilan TPK sebagai pengadilan khusus yang independen berada di lingkungan Peradilan Umum dan berkedudukan di setiap ibu kota Kabupaten/Kota yang daerah hukumnya meliputi daerah hokum Pengadilan Negeri yang bersangkutan melalui undangundang tersendiri, maka semua TPK akan diperiksa, diadili dan diputus oleh Pengadilan TPK ini. Dimana dengan tegas diatur bahwa proses pemeriksaan TPK akan diselesaikan dalam waktu paling lama 120 (seratus dua puluh) hari, oleh Majelis hakim yang terdiri atas hakim karir dan Hakim Ad Hoc yang berasal dari luar hakim karir yang memiliki pengetahuan di bidangnya untuk membantu menyelesaikan TPK yang sangat kompleks. Hal ini memperlihatkan bahwa secara teoritis keberadaan Pengadilan TPK secara sitematis diharapkan mampu mendorong percepatan pemberantasan TPK secara lebih struktural.

Pengadilan TPK yang ada sekarang telah membawa perubahan ke arah yang positif, dengan memberi peluang penyelenggaraan peradilan yang adil (fair trial) dan non diskriminatif. (Mudzakkir, 2011). Pengadilan TPK merupakan 
Sukmareni, Roni Efendi dan Riki Zulfiko: Perbedaan Hukum Acara Pengadilan Tindak...

pengadilan yang paling serius dalam melakukan pemberantasan korupsi di Indonesia. (Topo Santoso, 2011)

Pada penelitian ini penulis ingin mengetahui perbedaan hokum acara yang digunakan dalam Pengadilan TPK dengan hokum acara yang digunakan dalam Pengadilan umum, dengan mengangkat permasalahan sebagai berikut: Bagaimana hukum acara dari Pengadilan Umum dalam sistem peradilan pidana Indonesia? Bagaimana hukum acara dari Pengadilan TPK dalam sistem peradilan pidana Indonesia ? Apa perbedaan hokum acara Pengadilan TPK dibandingkan dengan hukum Pengadilan Umum dalam sistem peradilan pidana Indonesia?

Melalui penelitian ini diharapkan akan dapat diketahui hokum acara yang digunakan pada Pengadilan Umum dan Pengadilan TPK, serta perbedaan hokum acara yang digunakan dalam kedua Pengadilan tersebut.

\section{METODE PENELITIAN}

Kajian ini bersifat deskriptif (Nico Ngani, 2012), menggunakan pendekatan yuridis normatif, dalam hal ini pendekatan undang-undang (statute approach). Pendekatan undang-undang dilakukan dengan mendekati masalah yang diteliti hanya menggunakan data sekunder yang terdiri atas bahan hukum primer berupa perundang-undangan yang berkaitan dengan pengaturan pengadilan TPK. Hukum dikonsepkan sebagai normanorma tertulis yang dibuat oleh lembaga atau pejabat yang berwenang. Oleh karena itu, pengkajian yang dilakukan hanyalah terbatas pada peraturan perundangundangan (tertulis) yang terkait dengan masalah yang diteliti. Bahan hukum sekunder sebagai bahan hukum untuk memperjelas bahan hukum primer berupa buku, dokumen, hasil penelitian dan lainlain, serta bahan hukum tertier sebagai pelengkap bahan hukum sebelumnya berupa kamus hukum. Pengumpulan bahan hukum dilakukan melalui studi dokumen dan studi pustaka. Bahan hukum yang diperoleh dikelompokkan berdasarkan permasalahan yang diteliti (kategorisasi) dan di beri label sesuai dengan permasalahan yang diteliti, untuk memudahkan jika dibutuhkan dalam melakukan analisis. Analisis dilakukan secara kualitatif, dengan menggunakan hermeneutika (penafsiran) hukum.

\section{HASIL DAN PEMBAHASAN}

\section{Hukum Acara Pengadilan Umum Dalam Sistem Peradilan Pidana Indonesia}

Peradilan umum merupakan salah satu pelaku kekuasaan kehakiman bagi rakyat pencari keadilan pada umumnya. Sedangkan Hakim yaitu pejabat peradilan Negara yang diberi wewenang oleh undang-undang untuk mengadili sebagai rangkaian tindakan hakim untuk menerima, memeriksa dan memutus perkara pidana berdasarkan asa bebas, jujur dan tidak memihak di siding pengadilan menurut cara yang diatur dalam undang-undang (Pasal 1 UU Peradilan Umum 2009). Undang-undang yang dimaksudkan dalam ketentuan di atas adalah Undang-Undang Nomor 8 Tahun 1981 tentang Kitab Undang- 
Undang Hukum Acara Pidana (KUHAP) dan peraturan pelaksana lainnya dan UU Kekuasaan Kehakiman.

Peradilan sebagai penyelenggara kekuasaan Negara di bidang yudikatif yang berada di bawah Mahkamah Agung, secara konstitusional bertindak menyelenggarakan peradilan demi menegakkan hukum dan keadilan (to enforce the truth and justice) dalam kedudukannya sebagai pengadilan Negara (state court system) (M. Yahya Harahap, 2009)

Berdasarkan Pasal 25 UndangUndang Nomor4 Tahun 2004 (UU Kekuasaan Kehakiman 2004) dan Pasal 24 ayat (2) UUD Tahun 1945 badan peradilan yang berada di bawah Mahkamah Agung meliputi badan peradilan dalam lingkungan :

a. Peradilan Umum

Peradilan ini berwenang memeriksa, mengadili, dan memutus perkara pidana dan perdata sesuai dengan ketentuan peraturan perundang-undangan

b. Peradilan Agama

Peradilan ini berwenang memeriksa, mengadili, memutus, dan menyelesaikan perkara antara orang-orang yang beragama Islam sesuai dengan ketentuan peraturan perundang-undangan.

c. Peradilan Militer

Peradilan ini berwenang memeriksa, mengadili, dan memutus perkara tindak pidana militer sesuai dengan ketentuan peraturan perundang-undangan

d. Peradilan Tata Usaha Negara
Peradilan ini berwenang memeriksa, mengadili, memutus, dan menyelesaikan sengketa tata usaha negara sesuai dengan ketentuan peraturan perundangundangan.

Hakim pada Peradilan Umum adalah Hakim Karir, yang dalam pengangkatannya menurut Pasal 14 ayat (1) UU Peradilan Umum 2009 harus memenuhi persyaratan yaitu :

a. Warga negara Indonesia

b. Bertakwa kepada Tuhan Yang Maha Esa

c. Setia kepada Pancasila dan Undang-Undang Dasar Negara Republik Indonesia Tahun 1945

d. Sarjana hokum

e. Lulus pendidikan hakim

f. Mampu secara rohani dan jasmani untuk menjalankan tugas dan kewajiban

g. Berwibawa, jujur, adil, dan berkelakuan tidak tercela

h. Berusia paling rendah 25 (dua puluh lima) tahun dan paling tinggi 40 (empat puluh) tahun

i. Tidak pernah dijatuhi pidana penjara karena melakukan kejahatan berdasarkan putusan pengadilan yang telah memperoleh kekuatan hukum tetap.

Kemudian pada ayat (2) ditegaskan bahwa untuk dapat diangkat menjadi Ketua atau Wakil Ketua Pengadilan Negeri, hakim harus berpengalaman paling singkat 7 (tujuh) tahun sebagai hakim Pengadilan Negeri..

Pengangkatan hakim diatur dalam Pasal 16 (1) UU Peradilan Umum 2009 yang menyebutkan bahwa : 
Sukmareni, Roni Efendi dan Riki Zulfiko: Perbedaan Hukum Acara Pengadilan Tindak...

a. Hakim pengadilan diangkat oleh Presiden atas usul Ketua Mahkamah Agung

b. Hakim pengadilan diberhentikan oleh Presiden atas usul Ketua Mahkamah Agung dan/atau Komisi Yudisial melalui Ketua Mahkamah Agung. Usul pemberhentian hakim yang dilakukan oleh Komisi Yudisial sebagaimana dimaksud hanya dapat dilakukan apabila hakim yang bersangkutan melanggar Kode Etik dan Pedoman Perilaku Hakim.

Kemudian pada ayat (2) nya ditegaskan bahwa Ketua dan wakil ketua pengadilan diangkat dan diberhentikan oleh Ketua Mahkamah Agung. Sedangkan untuk dapat diangkat menjadi Panitera Pengadilan Negeri berdasarkan Pasal 28 UU Peradilan Umum 2004, seorang calon harus memenuhi syarat sebagai berikut:

a. Warga negara Indonesia.

b. Bertaqwa kepada Tuhan Yang Maha Esa.

c. Setia kepada Pancasila dan Undang-Undang Dasar Negara Republik Indonesia Tahun 1945.

d. Berijazah serendah-rendahnya sarjana muda hokum.

e. Berpengalaman sekurangkurangnya 3 (tiga) tahun sebagai Wakil Panitera, 5 (lima) tahun sebagai Panitera Muda Pengadilan Negeri, atau menjabat sebagai Wakil Panitera Pengadilan Tinggi

f. Sehat jasmani dan rohani.

Kemudian dalam Pengadilan Umum, panitera selama penyelenggaraan peradilan mempunyai kedudukan sebagai unsur pembantu pimpinan dalam melakukan managerial kantor, dan unsur pembantu hakim dalam proses penyelesaian perkara. Khususnya dalam tugas dan fungsi kewenangan Pengadilan, Panitera menjadi unsur yang sangat menentukan atas jaannya proses perkara sejak diterimaa, diperiksa, diadili sampai eksekusi. Panitera selaku pelaksana administrasi pengadilan memiliki 3 jenis tugas, yakni sebagai berikut (Abdul Mukhlis Hasan, 2017)

a. Pelaksana adminsitrasi perkara

Berkewajiban mengatur tugas tugas para pembantunya seperti wakil panitera, panitera muda dan panitera penganti (Pasal 27 ayat (1) UU Peradilan Umum). Daalam pelaksanaan tugas administrasi meliputi pelayanan administrasi perkara keuangan, penyusunan statistik perkara, dokumentasi, dan laporan perkara

b. Pendamping hakim selama persidangan

Selaku pendamping hakim atau Majelis Hakim dalam persidangan, panitera berkewajiban mencatat jalannya persidangan dan dari catata tersebut disusun Berita Acara Persidangan. Jika Panitera berhalangan akan dibantu tugasnya oleh Panitera Pengganti

c. Pelaksana putusan penetapan pengadilan

d. Tugas-tugas kejurusitaan lain.

Mengenai jangka waktu pemeriksaan tindak pidana di Pengadilan umum tidak diatur dalam KUHAP secara tegas 
jangka waktu pemeriksaan pada setiap tingkat pengadilan, yang ada hanya pengaturan tentang batas waktu penahanan, yang dapat dilakukan oleh hakim pada setiap tingkat pengadilan

\section{Hukum Acara Pengadilan TPK Dalam Sistem Peradilan Pidana Indonesia}

Pembentukan Pengadilan TPK sebagai pengadilan khusus secara filosofis didasarkan pada alasan sebagai berikut: (Igm Nurdjana, 2010)

a. Pemeriksaan terhadap kasus-kasus yang kompleks seperti pengadaan barang dan jasa, pertanahan, perpajakan dan yang berhubungan dengan kerusakan SDA dapat dilakukan secara lebih professional dan objektif dengan adanya hakim khusus (Hakim Ad Hoc) yang memiliki keahlian di bidangnya, sehingga tidak tergantung pada keterangan ahli saja sebagai alat bukti.

b. Sebagai perwujudan komitmen Pemerintah setelah meratifikasi United Nation Convention Again Corruption (UNCAC) melalui Undang-Undang Nomor 7 Tahun 2006 untuk melakukan pemberantasan TPK baik di sector public maupun swasta melalui reformasi perundang-undangan, salah satunya UU Pengadilan TPK.

c. Perkembangan TPK yang makin meluas dan meningkat yang melibatkan seluruh unsur penyelenggara Negara baik eksekutif, legislative mauun yudikatif dan merosotnya tingkat kepercayaan masyarakat terhadap kinerja hakim karir, hal ini memerlukan penanganan khusus melalui bantuan Hakim Ad Hoc.

Indikator kemandirian pengadilan TPK dapat dilihat dari independensi lembaganya, proses peradilannya dengan susunan dan anggota Majelis Hakimnya yang sudah dijamin kemandiriannya secara konstitusional dan perundangundangan lainnya yang tidak dapat dicampuri oleh Lembaga Negara lainnya. (M. Agus Santoso, 2012). Pada penjelasan umum UU Pengadilan TPK 2009 disebutkan bahwa Pengadilan TPK akan dibentuk di setiap ibu kota kabupaten/kota yang akan dilaksanakan secara bertahap mengingat ketersediaan sarana dan prasarana. Namun untuk pertama kali berdasarkan Undang-Undang ini, pembentukan Pengadilan TPK dilakukan pada setiap ibukota provinsi

Pada Pengadilan TPK ini dikenal Hakim Ad hoc sebagai bagian dari Majelis hakimnya, yang berasal dari unsur masyarakat yang memiliki keahlian khusus tertentu di bidangnya selama 15 tahun. Mereka diperlukan untuk memberikan keseimbangan terutama jika pengadilan dihadapkan pada kasus-kasus yang permasalahannya sangat kompleks. Tata Wijayanti dkk, 204) Kedudukan hakim karir dengan hakim ad hoc Dalam proses pemeriksaan perkara dalam Pengadilan Tindak Pidana Korupsi (Tipikor) adalah sejajar yaitu sama-sama mempunyai kewenangan untuk melakukan tugas-tugasnya sebagai 
Sukmareni, Roni Efendi dan Riki Zulfiko: Perbedaan Hukum Acara Pengadilan Tindak...

seorang hakim, yang membedakan hakim karir dengan hakim ad hoc adalah proses pengangkatannya. (Watuseka Gery, 2017)

Hakim ad hoc adalah hakim yang bersifat sementara yang memiliki keahlian dan pengalaman di bidang tertentu untuk memeriksa, mengadili, dan memutus suatu perkara yang pengangkatannya diatur dalam undang-undang (Pasal 1 angka 3 UU Peradilan Umum 2009 Pasal 1 angka 1 Peraturan Presiden Republik Indonesia Nomor 5 tahun 2013 tentang Hak Keuangan dan Fasilitas Hakim Ad Hoc). Peran hakim yang sangat penting dalam memberantas suatu kejahatan, maka kredibilitas dan moralitas hakim sebagai aparat penegak hokum dipertaruhkan untuk mengembalikan kepercayaan masyarakat terhadap sistem peradilan melalui pemberi an sanksi sekaligus untuk membuat efek jera kepada para koruptor.

Dalam memeriksa, mengadili, dan memutus perkara TPK dilakukan dengan majelis hakim berjumlah ganjil sekurangkurangnya 3 (tiga) orang hakim dan sebanyak-banyaknya 5 (lima) orang hakim, terdiri dari Hakim Karier dan Hakim ad hoc. Dalam hal majelis hakim sebagaimana dimaksud berjumlah 5 (lima) orang hakim, maka komposisi majelis hakim adalah 3 (tiga) banding 2 (dua) dan dalam hal majelis hakim berjumlah 3 (tiga) orang hakim, maka komposisi majelis hakim adalah 2 (dua) banding 1 (satu). Penentuan mengenai jumlah dan komposisi majelis hakim tersebut ditetapkan oleh ketua pengadilan masing-masing atau Ketua Mahkamah
Agung sesuai dengan tingkatan dan kepentingan pemeriksaan perkara kasus demi kasus. Sedangkan ketentuan mengenai kriteria dalam penentuan jumlah dan komposisi majelis hakim dalam memeriksa, mengadili, dan memutus perkara tindak pidana korupsi sebagaimana dimaksud diatur dengan Peraturan Mahkamah Agung (Pasal 26 UU Pengadilan TPK 2009).

Sedangkan mengenai batas waktu pemeriksaan TPK diatur dalam Pasal 27 ayat (1) UU Pengadilan TPK menegaskan bahwa "Ketua Pengadilan TPK menetapkan susunan majelis Hakim sebagaimana dimaksud dalam waktu paling lambat 3 (tiga) hari kerja terhitung sejak tanggal penerimaan penyerahan berkas perkara", dan menurut ayat. (2) "Sidang pertama perkara TPK wajib dilaksanakan dalam waktu paling lambat 7 (tujuh) hari kerja terhitung sejak penetapan majelis Hakim". Kemudian pada Pasal 29 nya dijelaskan bahwa "Perkara TPK diperiksa, diadili, dan diputus oleh Pengadilan Tindak Pidana Korupsi tingkat pertama dalam waktu paling lama 120 (seratus dua puluh) hari kerja terhitung sejak tanggal perkara dilimpahkan ke Pengadilan TPK. Sedangkan Pemeriksaan tingkat banding TPK diperiksa dan diputus dalam waktu paling lama 60 (enam puluh) hari kerja terhitung sejak tanggal berkas perkara diterima oleh Pengadilan Tinggi (Pasal 30). Selanjutnya pemeriksaan tingkat kasasi pada TPK diperiksa dan diputus dalam waktu paling lama 120 (seratus dua puluh) hari kerja terhitung sejak tanggal 
berkas perkara diterima oleh Mahkamah Agung (Pasal 31). Dalam hal putusan pengadilan di mintakan peninjauan kembali, pemeriksaan perkara TPK diperiksa dan diputus dalam waktu paling lama 60 (enam puluh) hari kerja terhitung sejak tanggal berkas perkara diterima oleh Mahkamah Agung (Pasal 32) UU Pengadilan TPK 2009.

\section{Perbedaan Hukum Acara Pengadilan TPK Dibandingkan dengan Hukum Acara Pengadilan Umum Dalam Sistem Peradilan} Pidana Indonesia

Secara umum pemeriksaan TPK didasarkan pada ketentuan yang belaku dalam hokum acara pidana biasa, namun ada beberapa pengaturan khusus dalam UU TPK dan UU Pengadilan TPK yang sudah diuraikan di atas yang menimbulkan terjadinya perbedaan antara hokum acara TPK dengan Hukum acara tindak pidana umum, antara lain:

\section{a. Independensi Lembaganya \\ Berhubungan Dengan Kedudukan \\ Dan Materi Tindak Pidana Yang \\ Menjadi Kewenangan}

Upaya penegakan hukum ini dilakukan dengan jalan membentuk suatu badan peradilan yang independen dalam menangani permasalahan khususnya seperti tindak pidana korupsi, agar badan peradilan tersebut dapat bertindak sesuai koridor hukum sehingga rekayasa penguasa dapat dihilangkan. Berdasarkan ideologi pancasila keadilan tidak boleh dibedakan atas dasar latar belakang sosial, ekonomi, politik, ideologi, etnisitas, ras, agama, warna kulit, maupun gender.

Jika dilihat istilah pengadilan khusus yang digunakan dalam UU Pengadilan TPK sejalan dengan Pasal 10 UU Kekuasaan Kehakiman, yang menyebutkan bahwa Pengadilan khusus dapat dibentuk dalam salah satu lingkungan Peradilan, dalam hal lingkungan Peradilan Umum. Sebelum keluarnya UU Pengadilan TPK ini tidak dikenal adanya Pengadilan khusus pada sistem hokum Indonesia, dalam Pasal 15 ayat (1) UU Kekuasaan Kehakiman 2009 hanya mengenal 4 lingkungan Peradilan yang ada di bawah Mahkamah Agung, yaitu Peradilan Umum, Peradilan Agama, Peradilan Tata Usaha Negara serta Peradilan Militer

Pada Pasal 8 ayat (1) UU Peradilan Umum 2009 dan penjelasannya menegaskan bahwa di lingkungan peradilan umum dapat dibentuk pengadilan khusus yang diatur dengan undang-undang. Diadakan pengkhususan pengadilan dimaksudkan adanya diferensiasi/spesialisasi di lingkungan peradilan umum dimana dapat dibentuk pengadilan khusus, misalnya pengadilan anak, pengadilan niaga, pengadilan hak asasi manusia, pengadilan tindak pidana korupsi, pengadilan hubungan industrial, pengadilan perikanan yang berada di lingkungan peradilan umum. Kemudian dalam ayat (2) ditambahkan bahwa pada pengadilan khusus dapat diangkat hakim ad hoc untuk memeriksa, mengadili, dan memutus perkara, yang membutuhkan 
Sukmareni, Roni Efendi dan Riki Zulfiko: Perbedaan Hukum Acara Pengadilan Tindak...

keahlian dan pengalaman dalam bidang tertentu dan dalam jangka waktu tertentu, Ketentuan mengenai syarat dan tata cara pengangkatan dan pemberhentian serta tunjangan hakim ad hoc diatur dalam peraturan perundang-undangan.

Selanjutnya Pasal 1 angka 5 (UU Peradilan Umum 2009) menyebutkan bahwa "Pengadilan Khusus adalah pengadilan yang mempunyai kewenangan untuk memeriksa, mengadili dan memutus perkara tertentu yang hanya dapat dibentuk dalam salah satu lingkungan badan peradilan yang berada di bawah Mahkamah Agung yang diatur dalam undang-undang”.

Perbedaan Pengadilan TPKi dengan Pengadilan pada umumnya terlihat pada materi tindak pidana yang menjadi wewenangnya, kewenangan pengadilan pada umumnya dalam lingkup tindak pidana di dalam KUHP, sedangkan materi tindak pidana yang menjadi wewenang Pengadilan TPK memiliki kewenangan terhadap tindak pidana khusus yang diatur di luar KUHP, dalam hal ini TPK dan TPPU dan tindak pidana yang dikategorikan TPK dan TPPU oleh undang-undang lainnya (Luhut M Pangaribuan, 2009)

b. Proses Peradilannya

1) Komposisi Majelis Hakim Dalam Pemeriksaan Di Sidang Pengadilan Baik Pada Tingkat Pertama, Banding Maupun Kasasi

Penyelesaian TPK menurut Pasal 10 ayat 4 UU Pengadilan TPK 2009 dan UU KPK, dilaksanakan oleh pengadilan khusus dengan majelis hakim yang terdiri atas dua komponen yaitu hakim karir dan hakim ad hoc. Diharapkan dengan adanya hakim ad hoc maka penegakan hukum terhadap tindak pidana korupsi semakin menemukan titik terang karena tindak pidana korupsi merupakan salah satu tindak pidana yang bersifat khusus (extra ordinary crime). Hakim ad hoc diharapkan dapat membantu hakim karir dalam menyelesaikan kasus tertentu sesuai dengan bidang keahliannya selama ini. (H. Nurdin; 2019; 169-170). Keahlian di sini dimaksudkan sejalan dengan kompleksitas perkara tindak pidana korupsi, baik yang menyangkut modus operandi, pembuktian, maupun luasnya cakupan tindak pidana korupsi antara lain di bidang keuangan dan perbankan, perpajakan, pasar modal, pengadaan barang dan jasa pemerintah. Komposisi majelis Hakim dalam pemeriksaan di sidang pengadilan baik pada tingkat pertama, banding maupun kasasi, terdiri atas Hakim Karir dan hakim Ad Hoc dengan jumlah Majelis minimal 3 paling banyak 5, sedangkan dalam pengadilan umum hanya ada 3 anggota Majelis yang semuanya terdiri atas hakim karir.

2) Jangka Waktu Penyelesaian Pemeriksaan Perkara Tindak Pidana Korupsi Pada Setiap Tingkatan Pemeriksaan

Jangka waktu penyelesaian pemeriksaan perkara TPK pada setiap tingkatan pemeriksaan, lebih cepat dibandingkan pemeriksaan tindak pidana biasa, hal ini jelas terlihat dari apa yang 
diatur dalam Pasal 29-32 UU Pengadilan TPK.

a) Penetapan susunan Majelis Hakim oleh Ketua Pengadilan TPK dalam waktu paling lambat 3 (tiga) hari kerja terhitung sejak tanggal penerimaan penyerahan berkas perkara.

b) Penetapan sidang pertama perkara TPK wajib dilaksanakan dalam waktu paling lambat 7 (tujuh) hari kerja terhitung sejak penetapan majelis Hakim.

c) Penetapan perkara TPK diperiksa, diadili, dan diputus oleh Pengadilan TPKi tingkat pertama dalam waktu paling lama 120 (seratus dua puluh) hari kerja terhitung sejak tanggal perkara dilimpahkan ke Pengadilan TPK. Pemeriksaan tingkat banding TPK paling lama 60 (enam puluh) hari kerja terhitung sejak tanggal berkas perkara diterima oleh Pengadilan Tinggi dan pemeriksaan tingkat kasasi TPK diperiksa dan diputus dalam waktu paling lama 120 (seratus dua puluh) hari kerja terhitung sejak tanggal berkas perkara diterima oleh Mahkamah Agung . Untuk peninjauan kembali, pemeriksaan perkara TPK diperiksa dan diputus dalam waktu paling lama 60 (enam puluh) hari kerja terhitung sejak tanggal berkas perkara diterima oleh Mahkamah Agung.

Penegasan waktu seperti ini tidak ditemukan dalam KUHAP, yang ada hanya pengaturan tentang batas waktu penahanan yang dapat dilakukan oleh hakim pada setiap tingkat pengadilan. Sedangkan proses pemeriksaan TPK diharapkan bisa berjalan dengan cepat sesuai dengan ketentuan dalam Pasal 29 sampai 31 di atas.

3) Sistem Pembuktian

Pada UU TPK 1999, TPK dirumuskan sebagai tindak pidana formil, sehingga pembuktian memiliki peranan yang sangat penting dalam penyelesaian kasus yang terjadi. Dalam hal ini pelaku TPK tetap diajukan ke pengadilan walaupun hasil TPK sudah dikembalikan kepada Negara. Selanjutnya pada penjelasan umum UU TPK 1999 ditegaskan bahwa dalam pembuktian TPK, dikenal pembuktian terbalik yang bersifat terbatas dan berimbang, dimana terdakwa mempunyai hak untuk membuktikan bahwa ia tidak melakukan TPK dan wajib memberikan keterangan tentang seluruh hartanya, harta benda istri atau suami, anak, dan harta benda setiap orang atau korporasi yang di duga mempunyai hubungan dengan perkara yang bersangkutan dan penuntut umum tetap berkewajiban untuk membuktikan.

Pembuktian dalam UU TPK memiliki perbedaan dibandingkan dalam KUHAP, dimana pada tindak pidana umum membuktikan di pengadilan merupakan kewajiban dari jaksa, sedangkan pada TPK selain dibuktikan oleh Jaksa, maka terdakwa juga berhak membuktikan bahwa dia tidak melakukan TPK dengan melajukan pembuktian terbalik 
Sukmareni, Roni Efendi dan Riki Zulfiko: Perbedaan Hukum Acara Pengadilan Tindak...

sebagaimana diatur dalam Pasal 12 B ayat (1) dan pasal 38 B UU TPK 2021.

Pembuktian terbalik ini diterapkan dalam pemeriksaan TPK dengan cara meminta atau memerintahkan terdakwa untuk membuktikan bahwa harta miliknya diperoleh secara sah. Apabila terdakwa tidak bisa membuktikan bahwa harta miliknya diperoleh dengan cara yang sah, bisa dijadikan alasan kalau terdakwa telah melakukan TPK (Nurhayani, 2015).

Alat bukti yang diajukan di dalam persidangan, juga terdapat tambahan dari alat bukti yang ada dalam Pasal 184 KUHAP, termasuk alat bukti yang diperoleh dari hasil penyadapan yang diperoleh secara sah berdasarkan ketentuan peraturan perundang-undangan. KUHAP tidak mengatur tentang penyadapan ini, namun pengaturan mengenai kedudukan penyadapan ditemukan dalam berbagai perundangundangan tersendiri, seperti UU ITE, UU TPK dan lainnya.

Menurut Pasal 184 ayat (1) KUHAP, alat bukti yang sah adalah keterangan saksi, keterangan ahli, surat, petunjuk dan keterangan terdakwa. Sedangkan dalam Pasal 26 a UU TPK 2021, dijelaskan bahwa hasil rekaman termasuk alat bukti petunjuk Dengan demikian maka dalam UU TPK alat bukti petunjuk dapat diperoleh dari alat bukti lain berupa informasi yang diucapkan, dikirim, diterima, atau disimpan secara elektronik dengan alat optic atau yang serupa dengan itu dan dokumen, yaitu setiap rekaman data atau informasi yang dapat dilihat, dibaca, dan atau di dengar yang dapat dikeluarkan dengan atau tanpa bantuan sarana, baik yang tertuang di atas kertas, benda fisik apapun selain kertas, maupun yang terekam secara elektronik, berupa tulisan, suara, gambar, peta, rancangan, foto, huruf, tanda, angka, atau perforasi yang memiliki makna. (Debby Natalia, 2015).

Penggunaan perluasan bukti elektronik ini diperlukan selaras dengan perubahan perilaku sosial kehidupan masyarakat dalam memanfaatkan media (convergance media), yang perlu dirumuskan melalui kebijakan hokum untuk penegakan hokum yang berhubungan dengan tindak pidana yang berhubungan dengan dunia maya.(Sri Ayu Astuti, 2017). Hal ini diperlukan demi aterciptanya kepastian hokum bagi aparat penegak hokum dalam memproses, memeriksa dan memutus suatu tindak pidana yang terjadi, begitu juga dengan TPK.

4) Pengadilan TPK Memiliki Kepaniteraan Khusus

Kepaniteraan khusus dalam pengadilan TPK ditegaskan pada Pasal 22 UU Pengadilan TPK dipimpin oleh seorang panitera, dengan susunan, persyaratan pengangkatan dan pemberhentian sesuai dengan ketentuan perundang-undangan. Sedangkan mengenai tugas, tanggung jawab, susunan organisasi dan tata kerja kepaniteraan khusus Pengadilan TPK menurut Pasal 23 UU Pengadilan TPK diatur dengan Peraturan Mahkamah Agung.

Berdasarkan Pasal 27 Peraturan Mahkamah Agung Nomor 7 Tahun 2015, 
Panitera Muda khusus mempunyai tugas melaksanakan administrasi perkara di bidang khusus, seperti TPK dan perkara khusus lainnya sesuai dengan ketentuan yang berlaku. Untuk menjalankan tugas ini Panitera Muda Khusus menurut Pasal 28 menyelenggarakan fungsi pelaksanaan pemeriksaan dan penelaahan berkas perkara khusus, pelaksanaan registrasi perkara khusus, pelaksanaan distribusi perkara khusus yang telah dilakukan register untuk diteruskan kepada Ketua Majelis Hakim dari Ketua Pengadilan Tinggi, pelaksanaan penghitungan, penyiapan dan pengiriman penetapan penahanan, perpanjangan penahanan dan penangguhan penahanan bagi perkara bidang pidana khusus; pelaksanaan penerimaan kembali berkas perkara yang sudah diputus dan diminutasi, pelaksanaan pengiriman salinan putusan Pengadilan Tinggi beserta berkas perkara bendel A kepada Pengadilan Pengaju, Pelaksanaan penyimpanan berkas perkara yang belum mempunyai kekuatan hokum yang tetap, menyerahkan berkas perkara yang sudah mempunyai kekuatan hokum tetap ke pada Panitera Muda Hukum, Melaksanakan urusan tata usaha kepaniteraan dan melaksanakan urusan tata usaha kepaniteraan dan fungsi lain yang diberikan oleh Panitera.

Panitera khusus dalam Pengadilan TPK menuntut keahlian yang lebih dibandingkan panitera umum, karena TPK melibatkan banyak orang dan permalasahannya kompleks, sehingga dalam pemeriksaannya juga membutuhkan panitera khusus yang diberikan pelatihan sesuai dengan tugas yang akan dilaksanakan mereka. Beda dengan tindak pidana umum, pada pengadilan TPK seseorang yang awalnya hanya sebagai saksi biasa saja beralih statusnya menjadi tersangka, apabila dalam pemeriksaan diperoleh indikasi terlibat dalam TPK yang sedang diperiksa. Dengan demikian Berita Acara Pemeriksaan TPK diharapkan lebih detail karena bisa sebagai dasar pengembangan perkara bagi pihak lain nantinya.

5) Penegasan pembagian tugas dan wewenang antara ketua dan wakil ketua Pengadilan TPK

\section{SIMPULAN}

Berdasarkan penelitian di atas ditemukan bahwa pemeriksaan perkara pidana di Pengadilan Umum dilaksanakan berdasarkan KUHAP dan UU Peradilan Umum dan ketentuan lainnya dengan lingkup kewenangan tindak pidana umum, sedangkan pemeriksaan pada Pengadilan TPK secara umum juga didasarkan pada KUHAP dan ketentuan perundang-undangan lainnya, sepanjang tidak ditentukan lain dalam UU Pengadilan TPK, dengan lingkup kewenangan TPK, TPPU dan Tindak pidana lainnya yang dalam perundangundangan dikategorikan sebagai TPK. Perbedaan antara Pengadilan Umum dengan Pengadilan TPK terlihat tidak hanya dalam lingkup kompetensi tindak pidananya saja, melainkan juga dalam pelaksanaan proses pemeriksaan dan aparat penegak hokum pelaksananya. Pengadilan TPK kewenangannya mengadili TPK, TPPU dan tindak pidana 
Sukmareni, Roni Efendi dan Riki Zulfiko: Perbedaan Hukum Acara Pengadilan Tindak...

dalam perundang-undangan lain yang dikategorikan sebagai TPK, sedangkan dari proses pemeriksaan, terdapat perbedaan, dimana pada 1) Pengadilan Umum Majelis Hakimnya semua terdiri atas Hakim Karir, sedangkan pada Pengadilan TPK Majelis Hakimnya gabungan antara Hakim Karir dan Hakim Ad Hoc, yang diangkat di luar Hakim Karir dari anggota masyarakat sesuai dengan bidang keahliannya yang dibutuhkan dalam penyelesaian TPK, 2) jangka waktu pemeriksaannya lebih cepat dibandingkan Pengadilan Umum, 3) Alat bukti dalam Pengadilan TPK selain alat bukti dalam Pasal 184 KUHAP yang digunakan dalam Pengadilan Umum, ditambah dengan hasil rekaman elektronik sebagai perluasan alat bukti petunjuk, 4) Pengadilan TPK juga memiliki Panitera Khusus yang dibentuk untuk membantu Hakim dalam memeriksa dan memproses pelaku TPK di Pengadilan.

\section{DAFTAR PUSTAKA}

Abdul Muchlis Hasan, (2017) Efektivitas Pelaksanaan Fungsi Panitera Dalam penyelesaian Perkara Pidana, Jurnal Al Hikam, ISSN 2089-0974, Volume 1 No 3, 2017

Ahmad Mujahidin, (2007). Peradilan Satu Atap di Indonesia,. PT Refika Aditama: Bandung.

Artidjo Alkostar. (2013). Korupsi Sebagai Xtra Ordinary Crime, Makalah, Training Pengarusutamaan Pendekatan Hak Asasi Manusia Dalam Pemberantasan Korupsi Di Indonesia Bagi Hakim Seluruh Indonesia.
Debby Natalia. (2015). Tinjauan Yuridis Terhadap Perluasan Alat Bukti Penyadapan Dalam Tindak Pidana Korupsi. Lex Crimen Vol.Iv/No.1/No.1/Jan-

Mar/20151441, Hlm 144, 149

H. Nurdin. (2019) Eksistensi Hakim Ad Hoc Pada Pengadilan Tindak Pidana Korupsi Dalam Sistem Kekusaan Kehakiman Meraja Journal, Vol. 2, No. 2, Juni 2019

Igm Nurdjana, (2010). Sistem Hukum Pidana dan Bahaya Laten Korupsi "Prespektif Tegaknya Keadilan Melawan Mafia Hukum",. Pustaka Pelajar: Yogyakarta.

Kurniasanti, Joko Setiyono, (2020). Penanggulangan Kejahatan Perompakan Laut Di Indonesia Berdasarkan Perspektif Hukum Pidana Internasional, JCH (Jurnal Cendekia Hukum) Volume 6 Nomor 1, September 2020 e-ISSN: 25801678 dan ISSN: 2355-4657 Open Access:

M, Yahya Harahap, (2009). Hukum Acara Perdata, Siar Grafika; Jakarta.

M. Agus Santoso. (2012). Kemandirian Pengadilan Tindak Pidana Korupsi Dalam Sistem Ketatanegaraan Di Indonesia, Yustisia Vol.1 No. 3 September - Desember 2012

Nico Ngani, (2012). Metode Penelitian dan Penulisan Hukum, Pustaka Yustitia,

Nurhayani, (2015) Pembuktian Terbalik Dalam Pemeriksaan Tindak Pidana Korupsi Di Indonesia , Jurnal IUS, Hukum dan Keadilan, E ISSN: 2447-815X P-ISSN: 2303-3827, 
Program Studi Magister Ilmu Hukum, Fakultas Hukum Iniversitas Mataram, Vol 3.Nomor 1 (2015)

Rikhi Benindo Maghaz. (2019). Permasalahan Penuntutan Terhadap Pelaku Penyalah Guna Narkotika di Wilayah Hukum Kejaksaan Negeri Padang, JCH (Jurnal Cendikia Hukum) Volume 4 Nomor 2 Maret 2019 e-ISSN :2580-1678 dan ISSN : $2355-4657$

Sri Ayu Astuti. (2017). Perluasan Penggunaan Bukti Elektronik (Evidence of Electronic) Terkait Ketentuan Alat Bukti Sah atas Perbuatan Pidana di Ruang Mayantara (Cyberspace) Pagaruyuang Law Jurnal Vol 1 No 1 Juli 2017

Suwardi, Pelaksanaan Asas Peradilan Cepat Dalam Perkara Tindak Pidana Korupsi (Studi Terhadap Penerapan Pasal 29 UndangUndang Nomor 46 Tahun 2009 Di Pengadilan Tindak Pidana Korupsi Pontianak) https://media.neliti.com/ media/publications/10679-IDpelaksanaan-asas-peradilan-cepatdalam-perkara-tindak-pidanakorupsi-studi-terha.pdf,
Tata Wijayanta dan Ari Hernawan. (2014) Studi Evaluatif Peran Hakim Ad Hoc Dalam Penyelesaian Perselisihan Hubungan Industrial Di Pengadilan Hubungan Industrial Yogyakarta, Jurnal Yustisia Vol. 3 No. 1 Januari - April 2014.

Mudzakkir, (2011). Pengadilan Tindak Pidana Korupsi: Tindak Pidana Biasa Penanganannya Luar Biasa (Corruption Court: Common Crime With Extraordinary Reduction) Jurnal Legislasi Indonesia, Vol 8 No 2. Juni 2011, Hlm 31, https://ejurnal.peraturan.go.id/index.php/jli/ article/view/360/242).

Kajian Pengadilan Khusus Tindak Pidana Korupsi yang dilakukan oleh Kemitraan dan LIPI, Jakarta, 2008, hal.3-4. dalam Topo Santoso, Urgensi Pembenahan Pengadilan Tindak Pidana Korupsi Dalam Mewujudkan Good Governance, Kementerian Hukum Dan Hak Asasi Manusia R.I. Badan Pembinaan Hukum Nasional Puslitbang Jakarta, 2011 